ISSN: 2302-8556

\title{
Pengaruh Kemampuan Teknik Personal dan Dukungan Manajemen Terhadap Kinerja SIA dengan Motivasi Kerja Sebagai Pemoderasi
}

\author{
I Putu Kurnia Adhi Parwa ${ }^{1}$ \\ Ni Luh Sari Widhiyani \\ ${ }^{1,2}$ Fakultas Ekonomi dan Bisnis Universitas Udayana (Unud), Bali, Indonesia \\ e-mail: kurniaadhiparwa@gmail.com
}

\begin{abstract}
ABSTRAK
Kinerja sistem informasi akuntansi merupakan gambaran mengenai tingkat pencapaian selama menggunakan sistem informasi akuntansi dalam periode tertentu. Penelitian ini bertujuan untuk mengetahui pengaruh kemampuan teknik personal dan dukungan manajemen puncak terhadap kinerja sistem informasi akuntansi dengan motivasi kerja sebagai pemoderasi. Populasi dalam penelitian ini adalah seluruh karyawan yang terlibat langung dalam penggunaan sistem informasi akuntansi pada26Kantor Pusat BPR yang terdapat di Kabupaten Gianyar. Teknik pemilihan sampel yang digunakan pada penelitian ini adalah teknik purposive sampling. Responden yang digunakan dalam penelitian ini adalah sebanyak 78 responden. Analisis data yang digunakan dalam penelitian ini adalah MRA. Berdasarkan hasil analisis, ditemukan bahwa kemampuan teknik personal dan dukungan manajemen puncak berpengaruh positif terhadap kinerja sistem informasi akuntansi dan motivasi kerja mampu memperkuat pengaruh kemampuan teknik personal dan dukungan manajemen puncak terhadap kinerja sistem informasi akuntansi.

Kata kunci: Kemampuan teknik personal; dukungan manajemen puncak; motivasi kerja; kinerja sitem informasi akuntansi.
\end{abstract}

\begin{abstract}
Accounting information system performance is a reflection of the level of achievement in using accounting information systems within a certain period. This research aims to know the influence of personal skills and top management supporton accounting information systems performance with the motivation of working as moderation variabel. The population in this research is all employees whouseaccounting information systemin the 26 head office BPR in Gianyar Regency. The sample selection technique used in this research is the purposive sampling technique. Respondents used in this research amounted to 78 respondent. Data analysis technique used in this research is MRA. Based on the results of the analysis it was found that the ability of personal techniques and topmanagement support has a positive effect on accounting information system performance and motivation of working is able to strengthen the relationship of the ability of personal techniques and topmanagement support on accounting information system performance.

Keywords: Ability of personal techniques;topmanagement support; motivation of working; accounting information system performance.
\end{abstract}

\section{PENDAHULUAN}

Era globalisasi saat ini, menuntut perusahaan untuk selalu memberikan informasi yang cepat dan akurat. Untuk itu, setiap perusahaan menerapkan berbagai sistem yang beroperasi secara terintegrasi. Perusahaan memiliki beberapa subsistem yang 
salah satunya adalah sistem informasi.Sistem informasi adalah sistem yang dibuat oleh manusia yang terdiri dari terdiri dari komponen-komponen yang saling terintegrasi. Sistem informasi dapat berbasis komputer ataupun manual. Tugas dari sistem informasi yaitu mengumpulkan, menyimpan, dan mengelola data dan memberikan output berupa informasi ke pengguna. Data yang hasilkan oleh sistem informasi lebih cepat, tepat dan akurat. Salah satu subsistem dari sistem informasi yang dapat menunjang tercapainya tujuan dari sebuah perusahaan adalah sistem informasi akuntansi (SIA). SIA berbasis komputer saat ini sudah diterapkan oleh berbagai organisasi dan perusahaan dalam mengelola aspek keuangannya guna menunjang kebutuhan terhadap informasi akuntansi yang akurat, relevan, andal, tepat waktu, jelas, konsisten serta dapat dijadikan bahan perbandingan.

Oleh karena pentingnya peran dari sistem tersebut, maka jaminan atas keberhasilan suatu sistem pada perusahaan sangat perlu diperhatikan. Keberhasilan suatu sistem dapat dikaitkan dengan kinerja yang dimiliki sistem tersebut.Tujuan kinerja sistem informasi akuntansi adalah untuk memberikan gambaran apakah sistem tersebut telah memberikan hasil yang sesuai dengan yang dibutuhkan serta sesuai dengan tujuan.Komara (2010)membagi kinerja sistem informasi menjadi dua bagian yaitu bagaimana kepuasan dari pengguna SIA atau user accounting information satisfaction dan bagaimana manfaat penggunaan SIA bagi pengguna SIA atau user accounting information system usage.Pembagian ini dilakukan untuk mengukur bagaimana kinerja dari sistem informasi dari sudut pandang pengguna sistem informasi. 
Pengelolaan aspek keuangan yang memanfaatkan SIA juga diterapkan pada sektor perbankan, salah satunya adalah pada Bank Perkreditan Rakyat (BPR).BPR merupakan salah satu lembaga keuangan bank yang berfungsi untuk menerima simpanan tetapi hanya dalam bentuk tabungan, deposito, dan/atau bentuk lainnya yang dipersamakan dengan itu serta berfungsi untuk menyalurkan dana ke masyarakat.Penerapan SIA pada BPR merupakan hal yang sangat penting karena dalam kegiatan operasionalnya. BPR memerlukan informasi akuntansi yang memiliki tingkat akurasi yang tinggi akurat serta disajikan pada waktu yang tepatagar dapat digunakan untuk melakukan pengambilan keputusan oleh manajemen (Lindawati, 2010).

Berdasarkan Rapat Kerja Nasional (Rakernas) dan Seminar Nasional Perhimpunan Bank Perkreditan Rakyat Indonesia (Perbarindo) yang dilaksanakan di Pontianak oleh Otoritas Jasa Keuangan (OJK) pada tanggal 26 Oktober 2016 yang membahas mengenai permasalahan dan tantangan BPR/BPRS (syariah), disampaikan bahwa terdapat 5 (lima) faktor yang menjadi tantangan dan permasalahan BPR yaitu Lack of Capital, Lack of Management, Lack of Governance, Lack of IT System, dan Lack of Government Policy. Salah satu faktor yang dinyatakan sebagai permasalahan dalam BPR/BPRS adalah Lack of IT System yaitu kelemahan dalam sistem informasi dan teknologi (IT). Selaras dengan hal tersebut, pada tanggal 29 Juni 2018, Perbarindo bekerja sama dengan The Finance mengadakan Seminar yang membahas mengenai tantangan yang harus dihadapi BPR hingga saat ini yaitu melakukan transformasi, khususnya dengan mengadaptasi kemajuan teknologi yang ada. 
Permasalahan tersebut tentunya memiliki kaitan erat dengan SIA berbasis komputer yang diterapkan di BPR. Kelemahan dalam sistem informasi dan teknologi tersebut dapat disebabkan oleh beberapa faktor, yaitu kurangnya pembaruan teknologi-teknologi yang digunakan baik berupa software ataupun hardware, dan masih minimnya kemampuan dan pengetahuan dari karyawan untuk menjalankan teknologi atau software terbaru yang digunakan di BPR. Permasalahan tersebut nantinya tentu sangat berpengaruh terhadap kinerja SIA yang diterapkan pada BPR.

Data kantor pusat BPR yang tersebar diseluruh Bali menurut Otoritas Jasa Keuangan pada Juni 2018 adalah sejumlah 135 BPR dengan 26 kantor pusat BPR berada di Kabupaten Gianyar. Kabupaten Gianyar memiliki BPR dengan jumlah terbanyak kedua setelah Kabupaten Badung, selain itu Kabupaten Gianyar yang merupakan kawasan seni sebagai daya tarik wisata ini mampu memicu pergerakan perekonomian masyarakatnya yang terbukti dari banyaknya jumlah Usaha Mikro Kecil dan Menengah (UMKM) yaitu sejumlah 75.224 UMKM yang terbagi menjadi beberapa sektor. Keberadaan para pelaku UMKM tersebut tidak terlepas dari bantuan kredit atau permodalan yang disalurkan oleh perbankan termasuk juga oleh BPR. Hal ini yang menjadi pemicu tingginya serapan kredit di kawasan seni ini sehingga BPR di Kabupaten Gianyar harus terus meningkatkan kinerjanya.

Dalam prosesnya, SIA melibatkan beberapa elemen pendukung, dua diantaranya adalah manusia dan peralatan yang digunakan untuk mengoperasikan SIA yang terdiri dari hardware yang berupa peralatan komputer serta software 
seperti Core Banking System, ACCURATE dan lain sebagainya. Peran manusia dalam mengoperasikan SIA merupakan hal yang penting dan sangat berpengaruh dengan peningkatan kinerja SIA. Peran seorang individu dalam mengoperasikan SIA dapat tercermin dari kemampuan teknik personal yang dimiliki oleh individu tersebut.

Kemampuan teknik personal adalah kemampuan yang dimiliki personal berdasarkan pengalamannya yang diperoleh dari pendidikan atau pelatihan yang pernah diikuti sebelumnya. Kemampuan teknik personal pengguna SIA menekankan pada kemampuan seorang individu dalam melakukan input datayang benar, pemrosesan data melalui pengoperasian, dan menghasilkan output yang berguna bagi pihak-pihak yang membutuhkan informasi akuntansi. Kesalahan individu dalam melakukan input data ataupun mengoperasikan SIA yang berbasis komputer bisa menjadi salah satu sumber buruknya kinerja SIA di BPR. Penggunaan sistem informasi akuntansi dalam perusahaan menuntut pemakai komputer (user) meningkatkan kemampuannya dalam menggunakan komputer (Sari, 2009).Oleh karena itu diperlukan kemampuan teknik pemakai yang baik untuk mencapai kinerja SIA yang optimal. Selain dari sisi karyawan, kinerja SIA yang baik akan lebih mudah dicapai jika manajemen puncak juga turut serta dalam pengembangan SIA.

Handayani (2010) mengemukakan bahwa terdapat adanya faktor internal organisasi yang mempengaruhi penggunaan sistem informasi antara lain dukungan manajemen (management support) yaitu tingkat dukungan secara umum yang diberikan oleh manajemen puncak dalam suatu organisasi. Dukungan 
manajemen puncak meliputi penyusunan tujuan atau penilaian tujuan, evaluasi usulan proyek pengembangan sistem informasi, mendefinisikan informasi dan proses yang diperlukan, melakukan program review dan rencana pengembangan sistem informasi (Meiryani, 2014). Manajemen puncak memiliki kewenangan untuk mengembangkan SIA agar memiliki kinerja lebih optimal misalnya dengan menambah kapasitas penyimpanan data, memperbaiki kualitas hardware dan software ataupun melakukan pengembangan SDM melalui pelatihan-pelatihan.

Penelitian Perbarini dan Juliarsa (2012) serta Dharmawan dan Ardianto (2017)menemukan tidak adanya pengaruh yang signifikan antara kemampuan teknik personal terhadap kinerja SIA, namun dalam penelitiannya ditemukan adanya pengaruh signifikan antara variabel dukungan manajemen puncak terhadap kinerja SIA. Gustiyan (2014)menemukan hal yang berbeda yaitu ditemukan adanya pengaruh signifikan dari hubungan variabel kemampuan teknik personal terhadap kinerja SIA dan tidak ditemukannya pengaruh yang signifikan dari hubungan dukungan manajemen puncak terhadap kinerja SIA.Krisnawati dan Suartana (2017), menyatakan bahwa kemampuan teknik personal dan motivasi kerja berpengaruh positif terhadap kinerja SIA. Sementara itu Septianingrum (2014) menemukan bahwa kemampuan teknik personal dan dukungan manajemen puncak berpengaruh positif terhadap kinerja SIA. Utama dan Suardhika (2014) menyatakan bahwa kemampuan teknik personal dan dukungan manajemen puncak tidak berpengaruh signifikan terhadap kinerja SIA.

Hasil-hasil penelitian sebelumnya yang tidak konsisten tersebut menjadi salah satu alasan peneliti dalam menggunakan variabel-variabel kemampuan 
teknik personal dan dukungan manajemen puncak. Selain itu, diduga terdapat variabel lain yang bersifat kontigensi yang diduga mampu memoderasi (memperkuat atau memperlemah) pengaruh variabel-variabel tersebut terhadap kinerja sistem informasi akuntansi yaitu motivasi kerja. Motivasi kerja dapat diartikan sebagai harapan dan preferensi hasil yang ingin dicapai individu dalam pekerjannya (Risnawatidan Nur, 2010). Menurut Robbins (2006), teori harapan (expectancy theory) menunjukkan bahwa kekuatan dari suatu kecenderungan bergantung pada kekuatan dari suatu harapan bahwa tindakan tersebut akan diikuti dengan hasil yang ada dan pada daya tarik dari hasil itu terhadap individu tersebut. Kemampuan teknik personal dan dukungan manajemen puncak memiliki hubungan yang erat dengan motivasi kerja dalam meningkatkan kinerja sistem informasi akuntansi.

Seorang karyawan BPR yang telah memiliki kemampuan teknik personal yang baik dan dukungan dari manajemen BPR juga telah optimal, namun tidak disertai dengan adanya motivasi tersendiri dari karyawan ataupun manajemen, tentunya apapun yang dikerjakan tidak akan menghasilkan hasil yang maksimal. Memiliki motivasi kerja yang tinggi akan mengeluarkan tingkat usaha yang tinggi sehingga akan menghasilkan hasil kerja yang baik. Hal ini tentunya dapat menjadi faktor untuk membantu tercapainya kinerja SIA yang baik. Disamping itu hasil penelitian sebelumnya juga mendukung pernyataan tersebut yaitu penelitian yang dilakukan oleh Muhindo (2014), yang menyatakan bahwa motivasi kerja berpengaruh positif terhadap kinerja SIA. Selain itu, penelitian Krisnawati dan 
Suartana (2017) juga menyimpulkan bahwa motivasi kerja berpengaruh positif terhadap kinerja SIA.

Simarmata (2015)menyatakan salah satu teori yang digunakan untuk memberikan bukti secara empiris mengenai penggunaan teknologi adalah Model Penerimaan Teknologi atau Technology Acceptance Model (TAM).Fred Davis pada tahun 1986 pertama kali memperkenalkan TAM. Fungsi dari TAM adalah untuk melakukan analisis dan memahami faktor-faktor yang mempengaruhi diterimanya penggunaan teknologi komputer. Berdasarkan analisis yang dilakukan oleh model ini, disimpulkan bahwa sistem yang mudah digunakan merupakan sistem yang lebih sering dipilih oleh pengguna dan berguna bagi pengguna.Model TAM merupakan pengembangan dari teori TRA atau Theory of Reasoned Action. TRA diperkenalkan olehAjzen pada tahun 1980.TRA merupakan teori mengenai tindakan seseorang selalu berdasarkan alasan tertentu. Individu akan bereaksi atau menentukan sikap bergantung pada persepsi dari individu tersebut.

Teori motivasi adalah suatu konsep yang menguraikan tentang kekuatankekuatan yang ada pada diri seseorang yang memulai dan mengarahkan perilaku atau dengan kata lain adalah suatu dorongan yang ditunjukan untuk memenuhi tujuan tertentu (Luthans, 2006).Istilah motivasi berasal dari bahasa Latin "movere" yang berarti dorongan atau menggerakkan.Motivasi adalah proses psikologis, atau lebih tepatnya proses emosional. Motivasi pada dasarnya adalah proses yang tidak kita sadari. Motivasi tiap orang berbeda, begitu juga setiap individu bervariasi dari waktu ke waktu. 
Sistem informasi akuntansi merupakan kumpulan sumber daya, seperti manusia dan peralatan yang dirancang untuk mengubah data keuangan dan data lainnya ke dalam bentuk sebuah informasi (Bodnar dan Hopwood, 2006).Tugas dari sistem adalah memproses data yang diinput oleh pengguna yang kemudian menghasilkan informasi akuntansi yang dapat digunakan sebagai dasar dalam pengambilan keputusan oleh pihak-pihak yang memerlukan informasi tersebut.Hall (2009) membagi sistem informasi akuntansi menjadi tiga sub sistem, yaitu transaction processing system (TPS), general ledger/ financial reporting system (GI/FRS) dan management reporting system (MRS).

Kinerja informasi akuntansi merupakan gambaran mengenai tingkat pencapaian pelaksanaan selama menggunakan SIA dalam periode tertentu (Krisnawati dan Suartana, 2017). Tujuan kinerja sistem informasi akuntansi adalah untuk memberikan gambaran apakah suatu sistem telah memberikan hasil yang sesuai dengan yang dibutuhkan serta sesuai dengan tujuan. Selain itu kinerja bertujuan untuk evaluasi pengembangan yang menekankan perubahan-perubahan pada periode tertentu, pemeliharaan sistem, serta untuk dokumentasi keputusankeputusan bila terjadi peningkatan (Artanaya dan Yadnyana, 2016)

Kemampuan teknik personal dapat diartikan sebagai kemampuan seseorang dalam mengoperasikan sistem dalam mengolah data menjadi sebuah informasi yang tepat, akurat, berkualitas serta dapat dipercaya bagi penggunanya (Suartika dan Widhiyani, 2017).Gunawan dan Tenaya (2017) menyatakan bahwa perusahaan akan sangat selektif ketika melakukan perekrutan karyawan, untuk memperoleh karyawan dengan kemampuan teknik personal yang baik.Seorang 
individu yang memiliki kemampuan teknik personal yang baik dapat menghasilkan informasi yang nantinya akan berguna dalam menciptakan laporan perencanaan dan laporan akhir yang akurat.

Dukungan manajemen puncak merupakan suatu kegiatan yang berdampak, mengarahkan dan menjaga perilaku manusia yang ditunjukkan oleh pimpinan tertinggi (Sarastini dan Suardikha, 2017). Salah satu faktor penting dari keberhasilan suatu SIA di sebuah perusahaan adalah seberapa besar peran manajemen puncak dalam mendukung perkembangan SIA didalam perusahaannya sendiri. Bentuk dukungan manajemen puncak berupa komitmen dan dukungan perusahaan berupa segala sumber daya yang dibutuhkan dalam melakukan sesuatu dalam perusahaan (Dharmawan dan Ardianto, 2017).

Motivasi kerja merupakan sistem nilai yang diyakini oleh anggota organisasi untuk mencapai tujuan organisasi. Motivasi kerja akan mendorong individu karyawan untuk memberikan kemampuan maksimalnya dalam mengerjakan tugas tertentu.Menurut Aries dkk., (2006), motivasi adalah pemberian dorongan-dorongan individu untuk bertindak yang menyebabkan orang tersebut berperilaku dengan cara tertentu yang mengarah pada tujuan.

Kemampuan teknik personal dapat diartikan sebagai kemampuan seseorang dalam mengoperasikan sistem dalam mengolah data menjadi sebuah informasi yang tepat, akurat, berkualitas serta dapat dipercaya bagi penggunanya. Ketika individu menggunakan sistem informasi, individu tersebut harus memiliki pengetahuan mengenai komputer dan sistem informasi yang akan digunakan. Pengetahuan yang cukup yang dimiliki pengguna akan meningkatkan kinerja dari 
SIA itu sendiri.Pernyataan serupa juga diungkapkan olehGustiyan (2014)dalam penelitiannya yang menemukan bahwa kemampuan teknik personal memiliki pengaruh yang signifikan terhadap kinerja SIA. Penelitian Septianingrum (2014), Rahmawati dan Pratomo (2015) serta Krisnawati dan Suartana (2017) yang menemukan adanya pengaruh positif dari kemampuan teknik personal terhadap kinerja SIA. Berdasarkan uraian dan hasil penelitian tersebutmaka dapat dirumuskan hipotesis pertama adalah:

$\mathrm{H}_{1}$ : Kemampuan teknik personal berpengaruh positif terhadap kinerja sistem informasi akuntansi.

Schwalbe (2010) mengemukakan bahwa manajemen puncak merupakan dukungan utama dalam pelaksanaan sistem informasi. Hal tersebut sangat penting karena sistem informasi membutuhkan sumber daya yang memadai dan visibilitas implementasi sistem informasi. Daft dan Marcic (2013) menyatakan bahwa dukungan manajemen puncak berkontribusi terhadap keberhasilan Kinerja SIA. Manajemen puncak akan menggunakan berbagai teknik dan kebijakan untuk implementasi SIA. Septianingrum (2014)juga menemukan hal yang serupa dari penelitian yang dilakukannya yang menemukan bahwa dukungan manajemen puncak memiliki pengaruh yang positif terhadap kinerja SIA. Selain itu, Antari, dkk (2015),Anggadini (2015), Perbarini dan Juliarsa (2012), serta Dharmawan dan Ardianto (2017) menyimpulkan bahwa dukungan manajemen puncak berpengaruh positif dan signifikan terhadap kinerja SIA. Berdasarkan uraian dan hasil penelitian tersebut, maka dapat dirumuskan hipotesis kedua adalah:

$\mathrm{H}_{2}$ : Dukungan manajemen puncak berpengaruh positif terhadap kinerja sistem informasi akuntansi. 
Melakukan penilaian dari kinerja sistem informasi harus memerhatikan juga pengetahuan dari pengguna sistem informasi karena ketika pengguna memiliki pengetahuan yang cukup mengenai pemahaman penggunaan sistem informasi maka kinerja dari sistem tersebut juga akan berjalan baik. Ketika sistem informasi berjalan baik maka informasi yang dihasilkan juga akan memiliki kualitas yang baik. Namun kemampuan teknik personal yang baik saja tidak cukup untuk meningkatkan kinerja SIA. Selain memliki kemampuan teknik personal yang baik, seorang karyawan juga harus memiliki motivasi kerja tersendiri dalam melaksanaan pekerjaannya. Motivasi kerja adalah salah satu faktor penting yang berperan dalam menimbulkan dorongan bagi karyawan agar memberikan kemampuan terbaiknya sehingga bisa menghasilkan kinerja SIA yang optimal.Menurut Muhindo (2014), motivasi kerja memiliki pengaruh yang positif terhadap kinerja SIA. Pengguna yang memiliki motivasi yang tinggi serta dapat mengoperasikan SIA dengan baik maka akan meningkatkan kinerja SIA itu sendiri.

$\mathrm{H}_{3}$ : Motivasi kerja mampu memperkuat pengaruh kemampuan teknik personal terhadap kinerja sistem informasi akuntansi.

Dukungan manajemen puncak merupakan salah satu faktor penting untuk mencapai kinerja sistem informasi yang baik. Manajemen juga harus memiliki motivasi untuk selalu mengembangkan perusahaannya. Apabila manajemen puncak memiliki motivasi tersendiri untuk selalu meningkatkan kinerja perusahaannya dengan memberikan dukungan penuh dalam pengembangan sistem informasi dan dukungan tersebut dapat diterima oleh pengguna informasi, maka akan memberikan kepuasan terhadap pengguna informasi tersebut. Seperti yang 
telah dikemukakan Rivai (2005), bahwa terdapat teori yang mendukung bahwa motivasi kerja dapat meningkatkan performance. Disamping itu hasil penelitian sebelumnya juga mendukung pernyataan tersebut yaitu penelitian Krisnawati dan Suartana (2017) yang menyimpulkan bahwa motivasi kerja berpengaruh positif terhadap kinerja SIA. Berdasarkan uraiandan hasil penelitian tersebut, maka dapat ditarik hipotesis keempat sebagai berikut.

$\mathrm{H}_{4}$ : Motivasi kerja mampu memperkuat pengaruh dukungan manajemen puncak terhadap kinerja sistem informasi akuntansi.

\section{METODE PENELITIAN}

Desain penelitian adalah kerangka kerja yang digunakan untuk melaksanakan penelitian.Pendekatan yang digunakan dalam penelitian ini adalah pendekatan kuantitatif yang berbentuk asosiatif.Desain dari penelitian terdapat dalam Gambar 1.

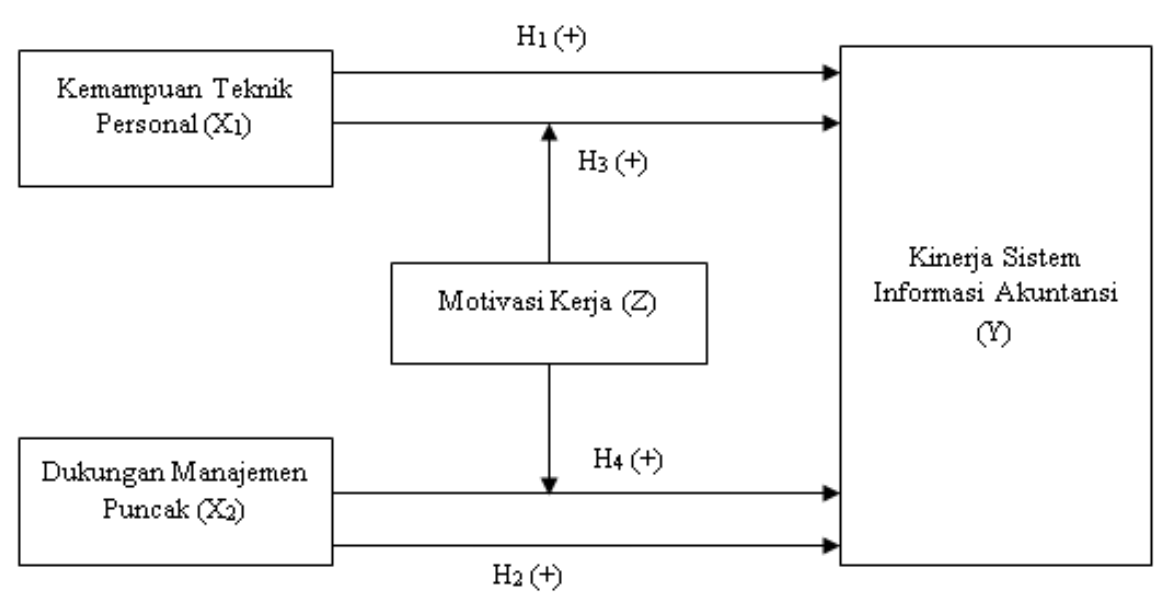

Gambar 1. Desain Penelitian 
Sumber: Data diolah,2018

Lokasi penelitian adalah tempat atau wilayah dimana penelitian tersebut dilakukan. Penelitian ini dilakukan padaseluruh Kantor Pusat Bank Perkreditan Rakyat (BPR) yang terdapat di Kabupaten Gianyar pada tahun 2018.Lokasi ini dipilih karena kabupaten Gianyar merupakan salah satu kabupaten di Bali dengan serapan kredit tertinggi. Oleh karena itu BPR di kabupaten Gianyar harus terus meningkatkan kinerjanya.Objek dari penelitian ini adalah kinerja sistem informasi akuntansi khususnya pada BPR yang telah menerapkan SIA di Kabupaten Gianyar pada tahun 2018.

Variabel terikat atau dependent variable yang dipilihadalah kinerja SIA.Sedangkan independent variable pada penelitian ini adalah kualitas laporan keuangan. Pada penelitian ini terdapat variabel moderasi atau moderating variable yaitu motivasi kerja.Masing-masing variabel akan diukur dengan menggunakan pernyataan dalam kuesioneryang menggunakan pengukuran skala likertlima pointdengan angka 1 menunjukkan sangat tidak setuju, angka 2 menunjukan tidak setuju, angka 3 menunjukkan ragu-ragu, angka 4 menunjukan setuju dan angka 5 menunjukkan sangat setuju.

Populasi dalam penelitian ini adalah seluruhkaryawan yang terlibat langsung dalam penggunaan SIA pada 26 kantor pusat BPR yang terdapat di Kabupaten Gianyar.Metode penentuan sampel yang digunakan dalam penelitian ini adalah dengan metode non probability sampling dengan teknik purposive sampling. Sampel dalam penelitian ini adalah karyawan yang dalam bekerja telah terlibat langsung dalam penggunaan SIA selama > 1 (satu) tahun, yaitu 1 (satu) 
staf karyawan pada bagian teller dan 2 (dua) staf karyawan pada bagian accounting.

Metode pengumpulan data yang digunakan dalam penelitian ini adalah metode wawancara dan kuesioner. Wawancaradilakukan dengan teknik wawancara tidak terstruktur terhadap pimpinan manajemen dan karyawan BPR yang meliputi data jumlah karyawan yang menggunakan SIA pada proses operasinya. Sedangkan, metode kuesioner dilakukan dengan menyebarkan secara langsung kepada sasaran responden ke setiap BPR yang telah ditentukan.

Instrument yang valid dan reliable merupakan syarat mutlak untuk mendapatkan hasil penelitian yang relevan (Sugiyono, 2017:199). Metode pengumpulan data pada penelitian ini adalah menggunakan metode kuesioner, maka kesungguhan responden dalam menjawab merupakan suatu hal yang penting. Berdasarkan pertimbangan tersebut maka setiap instrumen dan data penelitian dalam kuesioner penelitian perlu untuk diuji. Selanjutnya, sebelum melakukan analisis regresi dilakukanuji asumsi klasik yang terdiri dari uji normalitas, uji heteroskedastisitas, dan uji multikolinearitas yang diuji menggunakan program Statistical Package for Social Science (SPSS),kemudian Moderatated Regression Analysis (MRA)yang bertujuan untuk mengetahui peran suatu variabel yang dapat memerkuat atau memerlemah korelasi antara suatu variabel bebas (independen) terhadap variabel terikat (dependen)(Ghozali, 2016:213). Persamaan yang digunakan adalah sebagai berikut

$Y=\alpha+\beta_{1} X_{1}+\beta_{2} X_{2}+\beta_{3} Z+\beta_{4} X_{1} . Z+\beta_{5} X_{2} . Z+e$

Keterangan:

$\mathrm{Y} \quad=$ Kinerja Sistem Informasi Akuntansi 


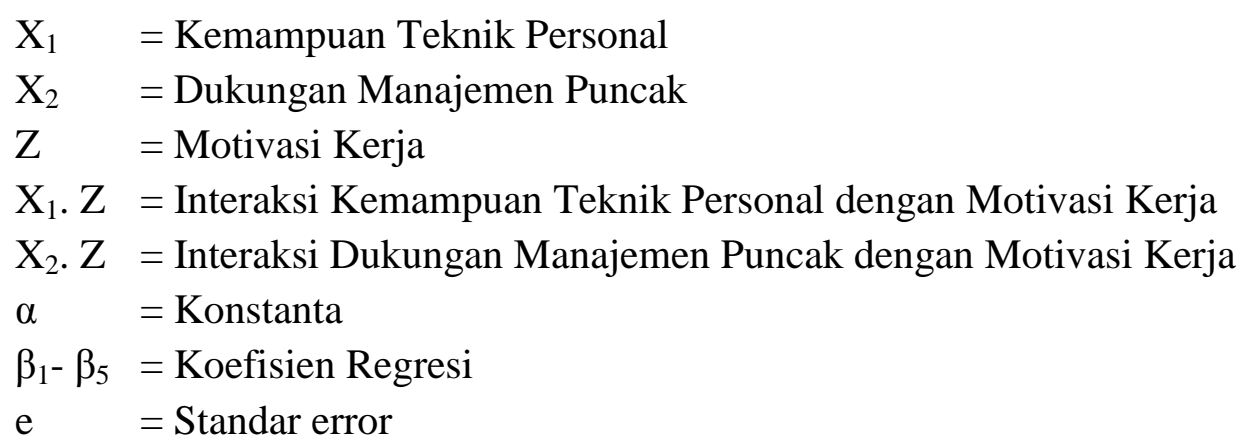

\section{HASIL DAN PEMBAHASAN}

Penelitian ini menggunakan instrumen berupa kuesioner, yang disebarkan ke 26 kantor pusat BPR yang tersebar di Kabupaten Gianyar.Responden dalam penelitian ini adalah karyawan yang dalam bekerja telah terlibat langsung dalam penggunaan SIA selama $>1$ (satu) tahun, yaitu 1 (satu) staf karyawan pada bagian teller dan 2 (dua) staf karyawan pada bagian accounting. Rincian pengiriman dan pengembalian kuesioner dapat dilihat pada Tabel 1.

Tabel 1.

Rincian Pengiriman dan Pengembalian Kuesioner

\begin{tabular}{lc}
\hline \multicolumn{1}{c}{ Uraian } & Jumlah \\
\hline Kuesioner yang tersebar & 78 \\
Kuesioner kembali & 78 \\
Kuesioner tidak kembali & 0 \\
Kuesioner gugur & 0 \\
Kuesioner yang digunakan & 78 \\
Response rate $=78 / 78 \times 100 \%$ & $100 \%$ \\
Usable response rate $=78 / 78 \times 100 \%$ & $100 \%$ \\
\hline Sumber: Data diolah 2018
\end{tabular}

Sumber: Data diolah, 2018

Berdasarkan Tabel1 dapat dilihat bahwa jumlah kuesioner yang disebar adalah sebanyak 78 kuesioner dengan tingkat pengembalian responden (response rate) sebesar $100 \%$ dan tingkat pengembalian yang dapat dianalisis (usable 
response rate) sebesar $100 \%$.Berdasarkan profil dari 78 responden yang berpartisipasi dalam penelitian ini diperoleh karakteristik responden yang meliputi jenis kelamin yang hasilnya menunjukkan bahwa responden perempuan lebih banyak dari pada responden laki-laki, berdasarkan umur yang menunjukkan mayoritas responden berumur 20 sampai 30 tahun, berdasarkan pendidikan yang menunjukkan bahwa pendidikan terakhir yang mendominasi adalah responden dengan jenjang pendidikan S1 dan berdasarkan masa kerjayang menunjukkan bahwa mayoritas responden telah bekerja selama 3 sampai 10 tahun.

Pengujian statistik deskriptif berguna untuk menjelaskan karakteristik variabel terutama mencakup nilai rata-rata (mean), nilai minimum dan nilai maksimum serta standar deviasi dari masing-masing variabel. Hasil dari statistik deskriptif tersebut dapat dilihat pada Tabel 2.

Tabel 2.

Hasil Uji Statistik Deskriptif

\begin{tabular}{cccccc}
\hline Variabel & $\mathrm{N}$ & Min. & Max. & Mean & Std. Deviation \\
\hline $\begin{array}{c}\text { Kemampuan Teknik Personal } \\
\left(\mathrm{X}_{1}\right)\end{array}$ & 78 & 11 & 30 & 24,1923 & 4,04538 \\
$\begin{array}{c}\text { Dukungan Manajemen Puncak } \\
\left(\mathrm{X}_{2}\right)\end{array}$ & 78 & 8 & 25 & 19,2692 & 3,76130 \\
$\quad$ & & & & & \\
Motivasi Kerja (Z) & 78 & 11 & 25 & 19,9615 & 3,12278 \\
Kinerja Sistem Informasi & 78 & 14 & 35 & 27,3077 & 4,18813 \\
Akuntansi (Y) & & & & & \\
Valid N (listwise) & 78 & & & &
\end{tabular}

Berdasarkan Tabel 2. dapat dilihat bahwa variabel kemampuan teknik personal $\left(\mathrm{X}_{1}\right)$ memiliki nilai minimum 11 , nilai maksimum 30 dengan nilai ratarata 24,1923 dan memiliki nilai standar deviasi sebesar 4,04538. Hal ini berarti 
bahwa terjadi penyimpangan nilai kemampuan teknik personal yang diteliti terhadap nilai rata-ratanya sebesar 4,04538. Variabel dukungan manajemen puncak $\left(\mathrm{X}_{2}\right)$ memiliki nilai minimum 8 , nilai maksimum 25 dengan nilai rata-rata 19,2692 dan memiliki nilai standar deviasi sebesar 3,76130. Hal ini berarti bahwa terjadi penyimpangan nilai dukungan manajemen puncak yang diteliti terhadap nilai rata-ratanya sebesar 3,76130.Variabel motivasi kerja (Z) memiliki nilai minimum 11, nilai maksimum 25 dengan nilai rata-rata 19,9615 dan memiliki nilai standar deviasi sebesar 3,12278. Hal ini berarti bahwa terjadi penyimpangan terhadap nilai motivasi kerja yang diteliti terhadap nilai rata-ratanya sebesar 3,12278.Variabel kinerja sistem informasi akuntansi (Y) memiliki nilai minimum 14, nilai maksimum 35 dengan nilai rata-rata 27,3077 dan memiliki nilai standar deviasi sebesar 4,18813 yang berarti bahwa terjadi penyimpangan terhadap nilai kinerja sistem informasi akuntansi yang diteliti terhadap nilai rata-ratanya sebesar $4,18813$.

Pengujian instrumen penelitian ini menggunakan uji validitas dan uji reliabilitas sebelum data dianalisis lebih lanjut dengan menggunakan program Statistic Package for Social Science (SPSS). Uji validitas dilakukan dengan melihatnilai pearson correlation. Berdasarkan hasil analisis dapat disimpulkan bahwa seluruh instrumen pernyataan dalam kuesioner yang digunakan untuk mengukur variabel kemampuan teknik personal, dukungan manajemen puncak, motivasi kerja dan kinerja sistem informasi akuntansi memiliki validitas konstruksi yang baik karena korelasi skor faktor dengan skor total (pearson correlation) positif dan nilainya lebih besar dari 0,3.Sedangkan uji reliabilitas 
dilakukan dengan melihat nilai cronbach's alpha. Berdasarkan hasil analisis dapat dilihat bahwa seluruh pernyataan pada instrumen penelitian dari masing-masing variabel memiliki nilaiCronbach's Alpha lebih dari 0,60. Hal ini berarti bahwa semua instrumen reliabel sehingga layak digunakan untuk melakukan penelitian.

Sebelum menguji dan menganalisis data dengan model regresi dilakukan uji asumsi klasik. Adapun pengujian asumsi klasik dalam penelitian ini, yaitu uji normalitasyang bertujuan untuk menguji apakah dalam model regresi variabel pengganggu atau residual memiliki distribusi normal, uji multikoinearitasyang bertujuan untuk menguji apakah pada model regresi ditemukan adanya korelasi antar variabel bebas, dan uji heteroskedastisitas yang bertujuan untuk menguji apakah dalam model regresi terjadi ketidaksamaan varians dari residual satu pengamatan ke pengamatan lain.Hasil uji asumsi klasik dapat dilihat pada Tabel 3. Tabel 4. dan Tabel 5. berikut ini.

Tabel 3. Hasil Uji Normalitas

\begin{tabular}{cc}
\hline & Unstandardized Residual \\
\hline $\mathrm{N}$ & 78 \\
Kolmogorov-Smirnov $Z$ & 0,465 \\
Asymp.Sig.(2-tailed) & 0,982 \\
\hline
\end{tabular}
Sumber: Data diolah, 2018

Berdasarkan Tabel 3.dapat dilihat bahwa nilai Kolmogorov Sminarnov (KS) sebesar 0,465, sedangkan nilai Asymp. Sig. (2-tailed) sebesar 0,982. Hasil tersebut mengindikasikan bahwa model persamaan regresi tersebut berdistribusi normal karena nilai Asymp. Sig. (2-tailed) 0,982lebih besar dari nilai alpha 0,05.

\section{Tabel 4.}

\section{Hasil Uji Multikoleniaritas}




\begin{tabular}{lccc}
\hline \multicolumn{1}{c}{ Variabel } & Tolerance & VIF & Keterangan \\
\hline Kemampuan teknik personal $\left(\mathrm{X}_{1}\right)$ & 0,798 & 1,254 & Bebas multikol \\
Dukungan manajemen puncak $\left(\mathrm{X}_{2}\right)$ & 0,797 & 1,254 & Bebas multikol \\
Motivasi kerja $(\mathrm{Z})$ & 0,995 & 1,005 & Bebas multikol \\
\hline
\end{tabular}

Sumber: Data diolah, 2018

Berdasarkan Tabel 4.dapat dilihat bahwa nilai tolerance dan VIF dari seluruh variabel tersebut menunjukkan bahwa nilai tolerance untuk setiap variabel lebih besar dari $10 \%(0,01)$ dan nilai VIF lebih kecil dari 10. Hal ini berarti model persamaan regresi bebas dari multikolinearitas.

Tabel 5.

Hasil Uji Heteroskedastisitas

\begin{tabular}{|c|c|c|c|c|c|}
\hline & \multicolumn{2}{|c|}{$\begin{array}{l}\text { Unstandardized } \\
\text { Coefficients }\end{array}$} & \multirow{2}{*}{$\begin{array}{r}\text { Standardized } \\
\text { Coefficients } \\
\text { Beta } \\
\end{array}$} & \multirow[b]{2}{*}{$\mathrm{t}$} & \multirow[b]{2}{*}{ Sig. } \\
\hline & B & Std. Error & & & \\
\hline (Constant) & 0,994 & 0,391 & & 2,546 & 0,013 \\
\hline Kemampuan Teknik Personal & $-0,005$ & 0,013 & $-0,047$ & $-0,359$ & 0,721 \\
\hline Dukungan Manajemen Puncak & $-0,003$ & 0,014 & $-0,027$ & $-0,205$ & 0,838 \\
\hline Motivasi Kerja & $-0,013$ & 0,018 & $-0,105$ & $-0,757$ & 0,452 \\
\hline Interaksi $X_{1} . Z$ & 0,000 & 0,000 & 0,124 & 0,869 & 0,388 \\
\hline Interaksi $\mathrm{X}_{2} \cdot \mathrm{Z}$ & $-0,001$ & 0,000 & $-0,229$ & $-1,837$ & 0,070 \\
\hline
\end{tabular}

Sumber: Data diolah, 2018

Pada Tabel 5.dapat dilihat bahwa nilai signifikansi seluruh variabel lebih besar dari 0,05 yang berarti tidak terdapat pengaruh antara variabel bebas terhadap absolute residual. Dengan demikian, model yang dibuat dapat dikatakan tidak mengandung gejala heteroskedastisitas. Berdasarkan seluruh hasil uji asumsi klasik yang telah dilakukan, dapat disimpulkan bahwa data yang digunakan dalam penelitian ini bebas dari uji asumsi klasik sehingga pengujianteknik Moderated Regression Analysis (MRA) dapat dilakukan. Hasil uji regresi moderasi dapat dilihat pada Tabel 6 .

Tabel 6.

Hasil Analisis Regresi Moderasi

\begin{tabular}{cccccc}
\hline Model & $\begin{array}{c}\text { Unstandardized } \\
\text { Coefficients }\end{array}$ & $\begin{array}{c}\text { Standardized } \\
\text { Coefficients }\end{array}$ & t & Sig. & $\begin{array}{c}\text { Hasil } \\
\text { Uji }\end{array}$
\end{tabular}




\begin{tabular}{|c|c|c|c|c|c|c|}
\hline & B & $\begin{array}{l}\text { Std. } \\
\text { Error }\end{array}$ & Beta & & & \\
\hline (Constant) & 0,018 & 0,072 & & 0,251 & 0,802 & \\
\hline X1 & 0,182 & 0,084 & 0,179 & 2,181 & 0,032 & Diterima \\
\hline $\mathrm{X} 2$ & 0,461 & 0,083 & 0,451 & 5,562 & 0,000 & Diterima \\
\hline $\mathrm{Z}$ & 0,043 & 0,078 & 0,043 & 0,553 & 0,582 & \\
\hline $\mathrm{X} 1 . \mathrm{Z}$ & 0,297 & 0,091 & 0,290 & 3,251 & 0,002 & Diterima \\
\hline $\mathrm{X} 2 . \mathrm{Z}$ & 0,232 & 0,088 & 0,227 & 2,638 & 0,010 & Diterima \\
\hline Adjusted $\mathrm{R}_{\text {square }}$ & $: 0,612$ & & & & & \\
\hline $\mathrm{F}_{\text {hitung }}$ & $: 25,267$ & & & & & \\
\hline Sig F $F_{\text {hitung }}$ & $: 0,000$ & & & & & \\
\hline
\end{tabular}

Sumber: Data diolah, 2018

Berdasarkan hasil analisis regresi seperti yang disajikan pada Tabel 6.maka persamaan regresi yang dihasilkan adalah sebagai berikut.

$$
Y=0,018+0,182 X_{1}+0,461 X_{2}+0,043 Z+0,297 X_{1} \cdot Z+0,232 X_{2} \cdot Z+e
$$

Nilai konstanta sebesar 0,018 memiliki arti apabila $\mathrm{X}_{1}$ atau kemampuan teknik personal, $\mathrm{X}_{2}$ atau dukungan manajemen puncak, Zatau motivasi kerja, hubungan antara $\mathrm{X}_{1}$.Zatau kemampuan teknik personal dengan motivasi kerjadan hubungan antara $\mathrm{X}_{2}$.Zatau dukungan manajemen puncak dengan motivasi kerja konstan, maka Y atau kinerja sistem informasi akuntansi meningkat sebesar 0,018 satuan.

Nilai koefisien $\beta_{1}$ sebesar 0,182 berartijika $X_{1}$ meningkat sebesar 1 satuan dengan anggapan variabel lainnya konstan, maka Y akan meningkat sebesar 0,182 satuan.Nilai koefisien $\beta_{2}$ sebesar 0,461 berarti jikaX ${ }_{2}$ meningkat sebesar 1 satuan dengan anggapan variabel lainnya konstan, maka Y akan meningkat sebesar 0,461 satuan.Nilai koefisien $\beta_{4}$ sebesar 0,297 berarti jikaX ${ }_{1} . Z$ meningkat sebesar 1 satuan dengan anggapan variabel lainnya konstan, maka Yakan meningkat sebesar 0,297 satuan.Nilai koefisien $\beta_{5}$ sebesar 0,232 berarti jika $X_{2}$.Zmeningkat sebesar 1 satuan dengan anggapan variabel lainnya konstan, maka Y akan meningkat sebesar 0,232 satuan. 
Berdasarkan Tabel 6. Dapat dilihat bahwa nilai Adjusted $\mathrm{R}^{2}$ sebesar 0,612. Hal ini berarti perubahan yang terjadi terhadapkinerja sistem informasi akuntansi dapat dipengaruhi secara signifikan oleh variabel kemampuan teknik personal $\left(\mathrm{X}_{1}\right)$, dukungan manajemen puncak $\left(\mathrm{X}_{2}\right)$, motivasi kerja $(\mathrm{Z})$, interaksi $\mathrm{X}_{1} \cdot \mathrm{Zdan}$ interaksi $\mathrm{X}_{2}$.Zsebesar $61,2 \%$, sedangkan sisanya sebesar $38,8 \%$ dijelaskan oleh faktor-faktor lain yang tidak diuji dalam penelitian ini.

Uji kelayakan model dilakukan dengan uji $\mathrm{F}$ yang bertujuan untuk menguji apakah semua variabel bebas yang dimasukkan dalam model mempunyai pengaruh secara bersama-sama (simultan) terhadap variabel terikat.Tabel 6 . menunjukkan bahwa nilai $F_{\text {hitung }}$ yang diperoleh adalah sebesar 25,267 dengan signifikansi 0,000. Signifikansi ini jelas lebih kecil dari Alpha $(\alpha=0,05)$ maka model regresi telah memenuhi prasyarat kelayakan model regresi dan berarti pada modelini seluruh variabel bebas secara simultan berpengaruh signifikan terhadap variabel terikat.

Uji t digunakan untuk mengetahui seberapa besar pengaruh variabel independen pada variabel dependen secara parsial.Hipotesis pertama menyatakan bahwa kemampuan teknik personal berpengaruh positif terhadap kinerja sistem informasi akuntansi. Berdasarkan hasil analisis pada Tabel 6.dapat dilihat bahwa nilai signifikansi kemampuan teknik personal $\left(\mathrm{X}_{1}\right)$ sebesar 0,032 dengan nilai koefisien regresi bernilai positif sebesar 0,182. Nilai Signifikansi $0,032<0,05$ mengindikasikan bahwa $\mathrm{H}_{1}$ diterima. Hasil ini mempunyai arti bahwa kemampuan teknik personal berpengaruh positif dan signifikan terhadap kinerja sistem informasi akuntansi.Hasil tersebut membuktikan bahwa apabila seorang 
karyawan memiliki kemampuan teknik personal yang baik (memiliki pengetahuantentang sistem informasi akuntansi, rutin mengikuti pelatihan dan mahir mengoperasikan komputer) akanmampu meminimalisir terjadinya kesalahan ataupun kegagalan sistem informasi dalam memberikan informasi yang dibutuhkan sehingga akan meningkatkan kinerja dari sistem informasi akuntansi.Hasil penelitian ini sesuai dengan hasil penelitian yang dilakukan oleh Rahmawati dan Pratomo (2015) serta Krisnawati dan Suartana (2017) yang menunjukkan bahwa adanya hubungan positif antara kemampuan teknik personal terhadap kinerja sistem informasi akuntansi.

Hipotesis kedua menyatakan bahwa dukungan manajemen puncak berpengaruh positif terhadap kinerja sistem informasi akuntansi. Berdasarkan hasil analisis pada Tabel 6.dapat dilihat bahwa nilai signifikansi dukungan manajemen puncak $\left(\mathrm{X}_{2}\right)$ sebesar 0,000 dengan nilai koefisien regresi bernilai positif sebesar 0,461. Nilai Signifikansi $0,000<0,050$ mengindikasikan bahwa $\mathrm{H}_{2}$ diterima. Hasil ini mempunyai arti bahwa dukungan manajemen puncak berpengaruh positif dan signifikan terhadap kinerja sistem informasi akuntansi.Hasil penelitian tersebut membuktikan bahwa dukungan manajemen puncak dan kinerja sistem informasi akuntansi berbanding lurus. Manajemen puncak berwenang untuk mengontrol serta berwenang dalam pengambilan keputusan, yang merupakan sumber kekuatan seorang atasan untuk lebih mengoptimalkan sistem yang telah ada. Dukungan manajemen puncak yang semakin tinggi (mendukung dalam proses perencanaan dan pengembangan sistem informasi akuntansi), maka kinerja sistem informasi akuntansi juga akan semakin 
meningkat.Hasil yang konsisten di dapat pada penelitian yang dilakukan oleh Septianingrum (2014) dan Dharmawan dan Ardianto (2017) yang menyatakan bahwa dukungan manajemen puncak berpengaruh positif dan signifikan terhadap kinerja sistem informasi akuntansi.

Berdasarkan hasil analisis regresi moderasi, nilai koefisien regresi variabel interaksi $\mathrm{X}_{1} . \mathrm{Z}$ adalah sebesar 0,297 dengan nilai signifikansi 0,002. Nilai signifikansi $0,002<0,050$ mengindikasikan bahwa $\mathrm{H}_{3}$ diterimayaitu motivasi kerja memperkuat pengaruh kemampuan teknik personal terhadap kinerja sistem informasi akuntansi.Hal tersebut mengindikasikan bahwa dengan adanya motivasi kerja akan mendorong karyawan untuk mengeluarkan dan meningkatkan kemampuan terbaiknya guna menghasilkan kinerja yang optimal, sehingga apabila pengguna sistem informasi akuntansi memiliki motivasi kerja dan mampu mengaplikasikan sistem informasi akuntansi dengan baik maka kinerja sistem informasi akuntansi akan semakin meningkat.Hasil penelitian ini sejalan dengan penelitian yang dilakukan oleh Muhindo (2014) yang menyatakan bahwa motivasi kerja berpengaruh positif terhadap kinerja sistem informasi akuntansi.

Hasil analisis regresi moderasi menunjukkan nilai koefisien regresi variabel interaksi $X_{2} . Z$ positif sebesar 0,232 dengan nilai signifikansi 0,010. Nilai signifikansi $0,010<0,050$ mengindikasikan bahwa hipotesis keempat yang menyatakan bahwa motivasi kerja memperkuat pengaruh dukungan manajemen puncak terhadap kinerja sistem informasi akuntansi dapat diterima.Memiliki motivasi kerja yang tinggi akan mengeluarkan tingkat usaha yang tinggi sehingga akan menghasilkan hasil kerja yang baik. Hal ini tentunya dapat menjadi faktor 
untuk membantu tercapainya kinerja sistem informasi akuntansi yang baik. Apabila dukungan dari manajemen BPR telah optimal dan disertai dengan motivasi tersendiri dari manajemen untuk selalu mengembangkan dan meraih hasil kerja yang maksimal, tentunya hal tersebut akan berpengaruh terhadap peningkatan kinerja sistem informasi akuntansi pada BPR itu sendiri. Hasil penelitian ini sesuai dengan hasil penelitian yang dilakukan oleh Krisnawati dan Suartana (2017) yang menyimpulkan bahwa motivasi kerja berpengaruh positif terhadap kinerja sistem informasi akuntansi.

\section{SIMPULAN}

Berdasarkan hasil analisis data dan pembahasan yang telah diuraikan pada bab sebelumnya, maka diperoleh simpulan bahwa kemampuan teknik personal berpengaruh positif dan signifikan terhadap kinerja sistem informasi akuntansi. Dukungan manajemen puncak berpengaruh positif dan signifikan terhadap kinerja sistem informasi akuntansi. Motivasi kerja mampu memperkuat pengaruh kemampuan teknik personal terhadap kinerja sistem informasi akuntansi. Motivasi kerja mampu memperkuat pengaruh dukungan manajemen puncak terhadap kinerja sistem informasi akuntansi.

Berdasarkan hasil penelitian dan simpulan yang telah diuraikan, maka saran yang dapat direkomendasikan adalah perusahaan diharapkan memberikan pelatihan-pelatihan dan pengenalan terhadap sistem yang akan diterapkan kepada karyawan. Pelatihan ini berguna untuk menghasilkan informasi yang akurat, relevan dan tepat waktu sehingga dapat meningkatkan kinerja sistem informasi 
akuntansi dan memajukan perusahaan. Pihak manajemen perusahaan disarankan agar selalu mendukung kelangsungan hidup perusahaan dengan mengevaluasi teknologi dan sistem informasi akuntansi yang digunakan serta memberikan karyawan pelatihan terhadap sistem tersebut sehingga dapat memberikan pelayanan yang optimal terhadap nasabahnya.Peneliti selanjutnya disarankan untuk menambah beberapa variabel lain seperti pendidikan dan pelatihan, insentif dan kompetensi karyawan. Serta memperluas lokasi penelitian dengan memilih lokasi penelitian yang berbeda.

\section{REFERENSI}

Ajzen, I. dan F. (1980). Theory of Reasoned Action. (Jogiyanto, Ed.) (1st ed.). Yogyakarta: Andi Publisher.

Anggadini, S. D. (2015). The Effect of Top Management Support and Internal Control of the Accounting Information Systems Quality and Its Implications on the Accounting Information Quality. Information Management and Business Review, 7(3).

Antari, K. R. W., Diatmika, I. P. G., \& Adiputra, I. M. P. (2015). Faktor-Faktor Yang Berpengaruh Terhadap Kinerja Sistem Informasi Akuntansi Pada Bank Perkreditan Rakyat di Kabupaten Buleleng. E-Journal S1 Ak Universitas Pendidikan Ganesha, 3(1).

Aries Setiawan, Ivan, \& Imam Ghozali. (2006). Akuntansi Keperilakuan Konsep dan kajian Empiris Perilaku Akuntan. (Badan Penerbit Universitas Diponegoro, Ed.). semarang.

Artanaya, P. Y., \& Yadnyana, I. K. (2016). Pengaruh Partisipasi Pemakai Terhadap Kinerja Sistem Informasi Akuntansi Dengan Kemampuan Pemakai Sebagai Variabel Moderasi, 15(2).

Bodnar, G. H., \& Hopwood, W. S. (2006). Sistem Informasi Akuntansi. (D. oleh A. Abadi \& Y. dan A. M. Tambunan, Eds.) (9th ed.). Jakarta: Salemba Empat.

Daft, R. L., \& Marcic, D. (2013). Understanding Management (8th ed.). South- 
Western Cangage Learning.

Dharmawan, J., \& Ardianto, J. (2017). Pengaruh Kemutakhiran Teknologi, Kemampuan Teknik Personal Sistem Informasi, Program Pelatihan Pengguna dan Dukungan Manajemen Puncak Terhadap Kinerja Sistem Informasi Akuntansi (Studi Empiris Pada Karyawan Perusahaan Retail Consumer Goods Wilayah Tangera. Ultima Accounting, 9(1).

Ghozali, I. (2013). Aplikasi Analisis Multivariat dengan Program IBM SPSS 21 (7th ed.). Semarang: Universitas Diponegoro.

Gunawan, I. M. P. A., \& Tenaya, A. I. (2017). Pengaruh Efektivitas Sistem Informasi Akuntansi Pada Kinerja Individual Dengan Kemampuan Teknik Personal Sebagai Pemoderasi. E-Jurnal Akuntansi Universitas Udayana, 20(2).

Gustiyan, H. (2014). Analisis Faktor - Faktor Yang Mepengaruhi Kinerja Sistem Informasi Akuntansi Pada Bank Perkreditan Rakyat (BPR) di Tanjungpinang.

Hall, J. A. (2009). Sistem Informasi Akuntansi (4th ed.). Jakarta: Salemba Empat. Handayani, R. (2010). Analisis Faktor-Faktor yang Menentukan Fektivitas Sistem Informasi pada Organisasi Sektor Publik. Jurnal Akuntansi Dan Keuangan, 12(1), 26-40.

Komara, A. (2010). Analisis Faktor-Faktor Yang Mempengaruhi Kinerja Sistem Informasi Akuntansi. Jurnal Manajemen, Akuntansi \& Sistem Informasi, 6(2), 143-160.

Krisnawati, N. P. A., \& Suartana, I. W. (2017). Pengaruh Kompetensi Karyawan, Motivasi Kerja, Komitmen Organisasi, Kemampuan Teknik Personal Terhadap Kinerja Sistem Informasi Akuntansi. Skripsi Sarjana Jurusan Akuntansi Pada Fakultas Ekonomi Dan Bisnis Unversitas Udayana, Bali.

Lindawati, I. S. (2010). Pemanfaatan Sistem Informasi dan Teknologi Informasi Pengaruhnya terhadap Kinerja Karyawan. Politeknik Negeri Sriwijaya.

Luthans, F. (2006). Perilaku Organisasi (10th ed.). Yogyakarta: PT. Andi.

Meiryani. (2014). Influence of Top Management Support on the Quality of Accounting Information System and Its Impact on the Quality of Accounting Information, 5(11).

Muhindo. (2014). Impact of Accounting Information Systems on Profitability of Small Scale Businesses: A Case of Kampala City in Uganda. International Journal of Academic Research in Management (IJARM), 3 (2). 
Perbarini, N. K. A., \& Juliarsa, G. (2012). Analisis Faktor-Faktor yang Mempengaruhi Kinerja Sistem Informasi Akuntansi Pada LPD di Kecamatan Denpasar Utara. E-Jurnal Akuntansi Universitas Udayana.

Rahmawati, S. A., \& Pratomo, D. (2015). Pengaruh Partisipasi Pengguna Sistem Informasi dan Kemampuan Pengguna Sistem Informasi terhadap Kinerja Sistem Informasi Akuntansi. (Studi terhadap Karyawan Pengguna Sistem Informasi Akuntansi AP2T (Aplikasi Pelayanan Pelanggan Terpadu) PT. PLN (Persero) . E-Proceeding of Management Universitas Telkom, 2(3).

Rivai, V. (2005). Manajemen Sumber Daya Manusia untuk Perusahaan, dari Teori ke Praktik. Jakarta: PT. Raja Grafindo Persada.

Robbins, S. P. (2006). Perilaku Organisasi (alih bahasa Drs. Benjamin Molan). (Edisi Bahasa Indonesia, Ed.). Klaten: PT Intan Sejati.

S., R. R., \& Nur, G. M. (2010). Teori-teori Psikologi. Yogyakarta: Ar Ruz Media. Sarastini, N. P. E., \& Suardikha, I. M. S. (2017). Pengaruh Pelatihan dan Pendidikan, Dukungan Manajemen Puncak dan Kemampuan Teknik Pemakai SIA Pada Kinerja Individual. E-Jurnal Akuntansi Universitas Udayana, 20(2).

Sari, M. M. R. (2009). Pengaruh Efektivitas Penggunaan dan Kepercayaan terhadap Teknologi Sistem Informasi Akuntansi terhadap Kinerja Individual pada Pasar Swalayan di Kota Denpasar. Jurnal Ilmiah Akuntansi Dan Bisnis, $4(1)$.

Schwalbe, K. (2010). Information Technology Project Management (6th ed.). Thomson Course Technology.

Septianingrum, P. A. (2014). Pengaruh Dukungan Top Management, Kemampuan Pengguna, Serta Adanya Pelatihan dan Pendidikan Pengguna Terhadap Kinerja Sistem Informasi Akuntansi (Studi Kasus Pada BPJS Ketenagakerjaan Semarang dan D.I Yogyakarta). Skripsi Sarjana Jurusan Akuntansi Pada Fakultas Ekonomi Universitas Negeri Yogyakarta.

Simarmata, M. T. . (2015). Model Penerimaan Teknologi (Technology Acceptance Model). Medan: Fakultas Ekonomi Universitas HKBP Nommensen.

Suartika, K. A., \& Widhiyani, N. L. S. (2017). Kemampuan Teknik Personal Pada Efektivitas Penggunaan Sistem Informasi Akuntansi dengan Pendidikan dan Pelatihan Sebagai Pemoderasi. E-Jurnal Akuntansi Universitas Udayana, $18(2)$. 
ISSN: 2302-8556

E-Jurnal Akuntansi Universitas Udayana

Vol.27.3.Juni (2019): 2239-2267

Sugiyono. (2016). Metode Penelitian Pendidikan Pendekatan Kuantitatif, kualitatif, dan $R \& D$. Bandung: Alfabeta.

Utama, I. D. G. B., \& Suardhika, I. M. S. (2014). Faktor-Faktor Yang Memengaruhi Kinerja Sistem Informasi Akuntansi Pada Lembaga Perkreditan Desa. E-Jurnal Akuntansi Universitas Udayana, 3(9). 